\title{
THE FRIGOPROTECTIVE EFFECT OF "GLUCOSAMINE C-BCPP" DIETARY SUPPLEMENT AND THE ROLE OF ITS COMPONENTS
}

\author{
E.V.Bondarev, S.Yu.Shtrygol', Yu.Yu.Shtrygol', A.S.Shalamay \\ National University of Pharmacy \\ PJSC SIC "Borshchahivskiy CPP"
}

Key words: frigoprotective effect; glucosamine hydrochloride; ascorbic acid; acute hypothermia

The effect of "Glucosamine C-BCPP" dietary supplement on the survival time of animals with acute hypothermia in experiments in mice has been determined. It has been found that with intragastric introduction of "Glucosamine C-BCPP" dietary supplement (its composition: glucosamine hydrochloride and ascorbic acid) to animals a significant increase in the the survival time compared to the the untreated group is observed on the model of acute hypothermia. The frigoprotective effect of "Glucosamine C-BCPP" is mainly due to glucosamine hydrochloride, the role of ascorbic acid is less.

Treatment and prevention of acute cold trauma is one of the most important problems of modern medicine and pharmacy both in peacetime and in wartime, and requires in-depth study of the mechanisms of the body adaptation to low temperatures $[2,5,6]$. Cold trauma refers to serious injuries, and it is an important cause of disability $[16,18,20]$.

In recent years there is a clear tendency towards increasing the number of injured victims of the cold in temperate regions. Every year more than 12000 cases of such injury in Ukraine, more than 20000 cases in Russia are recorded. Most of the victims of the cold need hospital treatment; mortality exceeds $10 \%[6,12,19]$.

In the pathogenesis of acute cold trauma hypoxia of the brain and other organs, disorders of the central nervous, cardiovascular, respiratory, excretory, endocrine systems, the gastrointestinal tract and the skin are involved. The course of these disorders causes the complexity of treatment and the consequences of hypothermia $[1,8,14,18,19]$.

Therefore, the search for new frigoprotective agents is an urgent task. In our previous studies it has been found that glucosamine hydrochloride $(\mathrm{G} \mathrm{h} / \mathrm{chl})$, a drug with the anti-inflammatory activity and a number of other pharmacological properties, is an effective frigoprotective agent that exceeds another salt - glucosamine sulphate $[3,4,9]$. Glucosamine is an important component of biological membranes; it is contained in large quantities in the brain, kidney, liver and skin [7].

On the model of acute hypothermia $\mathrm{G} \mathrm{h} / \mathrm{chl}$ in the dose of $50 \mathrm{mg} / \mathrm{kg}$ improves survival rate of animals, motor activity, muscle tone, coordination and physical endurance, normalizes the renal function in the recovery period. All these advantages substantiate expediency of in- depth studies of $\mathrm{G} \mathrm{h} / \mathrm{chl}$ as a potential frigoprotective agent. Most glucosamine drugs registered at the Ukrainian market contain glucosamine sulphate ("Artron", "Dona", etc.). Only one dietary supplement includes $\mathrm{G} \mathrm{h} / \mathrm{chl}$ in its composition in combination with ascorbic acid ("Glucosamine C-BCPP" produced by "Borshchahivskiy CPP").

Vitamin $\mathrm{C}$ (ascorbic acid) has the metabolic action; it is involved in the regulation of redox processes, carbohydrate metabolism, blood coagulation, tissue regeneration, and reduces vascular permeability. This vitamin possesses antiplatelet and distinct antioxidant properties, regulates immunological reactions, promotes phagocytosis, and increases resistance to infection [17].

The aim was to study the effect of "Glucosamine C-BCPP" dietary supplement and its components $\mathrm{G} \mathrm{h} / \mathrm{chl}$ and ascorbic acid on the survival time in mice under conditions of acute cold trauma.

\section{Materials and Methods}

The research was conducted in summer on white randombred female mice weighing 28-32 g; they were kept in standard vivarium conditions in accordance with the GLP rules. During our work the requirements of the EU Directive on the protection of animals used for experimental and other scientific purposes were performed [10].

To simulate cold injury mice were placed in individual plastic cases with the size of $8 \times 8 \times 15 \mathrm{~cm}$, which do not restrict access to the air. The animals were placed in the cases to the "Nord Inter-300" freezer at $-18^{\circ} \mathrm{C}$, and the survival time was determined [15].

"Glucosamine C-BCPP", G h/chl, ascorbic acid or $0.9 \%$ solution of $\mathrm{NaCl}$ (control) were administered intragastrically (i/g) for $30 \mathrm{~min}$ prior to acute cold trauma, i.e. in the preventive mode. Laboratory animals were di- 
vided into 4 groups according to the drug that they received, the dose and the route of administration: group 1 - untreated animals $(\mathrm{n}=8), \mathrm{NaCl}$ solution $(0.1 \mathrm{ml} / 10 \mathrm{~g})$ was administered to these animals; group 2 - "Glucosamine C-BCPP" in the dose of $82.5 \mathrm{mg} / \mathrm{kg}$ (the dose is equivalent to $50 \mathrm{mg} / \mathrm{kg}$ of $\mathrm{G} \mathrm{h} / \mathrm{chl})+$ cold injury $(\mathrm{n}=8)$; group $3-\mathrm{G} \mathrm{h} / \mathrm{chl} / 50 \mathrm{mg} / \mathrm{kg}+$ cold injury $(\mathrm{n}=8)$; group $4-$ ascorbic acid (Darnitsa) in the dose of $4 \mathrm{mg} / \mathrm{kg}+$ cold injury $(\mathrm{n}=8)$. The dose of $4 \mathrm{mg} / \mathrm{kg}$ of ascorbic acid was equivalent to the dose that animals received with "Glucosamine C-BCPP" dietary supplement in the dose of $82.5 \mathrm{mg} / \mathrm{kg}$.

The survival time of mice was selected as a criterion of sensitivity to cold. For statistical analysis of the results Student t-test was used in normal distribution or White nonparametric criterion $\mathrm{W}$ - when it was absent. Differences were considered to be statistically significant at $\mathrm{p}<0.05$.

\section{Results and Discussion}

In the test of acute hypothermia in mice the differences in the survival time listed in Table were observed.

Analysis of the data in Table indicates that "Glucosamine C-BCPP" in the dose of $82.5 \mathrm{mg} / \mathrm{kg}$ significantly increases the survival time of the animals with respect to the control pathology group by $33 \%$ and $16.1 \%$ compared to ascorbic acid. Under the action of $\mathrm{G} \mathrm{h} / \mathrm{chl}$ in the dose of $50 \mathrm{mg} / \mathrm{kg}$ the survival time of mice with acute cold trauma statistically significantly increases compared to the control (on average $+33.5 \%$ ) and $16.7 \%$ compared to the value against the background of ascorbic acid.

Ascorbic acid in the dose of $4 \mathrm{mg} / \mathrm{kg}$ in animals with acute cold trauma significantly increases the survival time by $20.2 \%$ compared to the untreated group.

The changes identified, namely increase in the survival time of the animals against the background of acute cold trauma, show a marked frigoprotective effect of the investigated drug and its components. The highest effect (almost identical) is provided by $\mathrm{G} \mathrm{h} / \mathrm{chl} 50 \mathrm{mg} / \mathrm{kg}$ and "Glucosamine C-BCPP" in the dose of $82.5 \mathrm{mg} / \mathrm{kg}$ equivalent to $\mathrm{G} h / \mathrm{chl}$.

The increased survival time under the action of $\mathrm{G} \mathrm{h} / \mathrm{chl}$ can be explained by a wide range of the pharmacological activity, such as anti-inflammatory, cerebroprotective properties [9] associated with the effect on neurotransmitter and metabolic processes in the brain, improvement of its blood supply, a possible positive impact on the systemic circulation, microcirculation, energy metabolism, etc. $[4,7]$.

Almost all body systems participate in stress reaction, but to a greater extent stress is associated with the hypothalamus-pituitary-adrenal gland axis and the immune system [11]. Vitamin C plays a crucial role in the synthesis of steroids, which are important in the mechanism of resistance in cold injury. Thus, ascorbic acid
The effect of glucosamine hydrochloride, "Glucosamine C-BCPP" and vitamin C on the survival time of mice under conditions of acute hypothermia

\begin{tabular}{|l|c|c|}
\hline \multicolumn{1}{|c|}{$\begin{array}{c}\text { Group, the number } \\
\text { of animals }\end{array}$} & $\begin{array}{c}\text { The survival } \\
\text { time, min }\end{array}$ & $\begin{array}{c}\% \text { Change to } \\
\text { the untreated } \\
\text { group }\end{array}$ \\
\hline $\begin{array}{l}\text { 1. Untreated group } \\
\text { (cold injury), } \mathrm{n}=8\end{array}$ & $46.60 \pm 4.25$ & - \\
\hline $\begin{array}{l}\text { 2. Glucosamine C-BCPP, } \\
82.5 \mathrm{mg} / \mathrm{kg}+\text { cold injury, } \\
\mathrm{n}=8\end{array}$ & $69.60 \pm 3.80^{*}$ & +33 \\
\hline $\begin{array}{l}\text { 3. Glucosamine } \\
\text { hydrochloride, } \\
50 \text { mg/kg + cold injury, } \\
\mathrm{n}=8\end{array}$ & $\begin{array}{c}70.10 \pm 4.25^{*} \\
\begin{array}{l}4 . \text { Ascorbic acid, } \\
4 \mathrm{mg} / \mathrm{kg}+\text { cold injury, } \\
\mathrm{n}=8\end{array}\end{array}$ & $\begin{array}{c}58.40 \pm 3.01 \\
* / * * * * *\end{array}$ \\
\hline
\end{tabular}

Note: * - statistically significant differences when compared to the untreated group, $p<0.05$; * - statistically significant differences when compared to the group receiving glucosamine hydrochloride, $50 \mathrm{mg} / \mathrm{kg}, \mathrm{p}<0.05$; *** - statistically significant differences when compared to the group receiving "Glucosamine C-BCPP", $82.5 \mathrm{mg} / \mathrm{kg}, \mathrm{p}<0.05$.

is completely absent in the human adrenal glands after lethal hypothermia [13]. Vitamin C is also important for formation of norepinephrine - a mediator of the sympathetic nervous system, which activation is involved in the stress reaction caused by cold injury. These aspects of the mechanism of action of ascorbic acid explain its protective effect revealed in acute hypothermia. However, according to the results $\mathrm{G} h / \mathrm{chl}$ plays a key role in the composition of "Glucosamine C-BCPP" dietary supplement.

\section{CONCLUSIONS}

1. "Glucosamine C-BCPP" dietary supplement in the dose of $82.5 \mathrm{mg} / \mathrm{kg}$ possesses a marked frigoprotective effect increasing the survival time of mice with acute hypothermia by $33 \%$.

2. The protective effect of "Glucosamine C-BCPP" dietary supplement is mainly due to the influence of glucosamine hydrochloride, which increases the survival time of animals by $33.5 \%$ in the equivalent dose of $50 \mathrm{mg} / \mathrm{kg}$. Ascorbic acid, which per se has a moderate frigoprotective effect in the equivalent dose of $4 \mathrm{mg} / \mathrm{kg}$, does not practically affect frigoprotective action of glucosamine hydrochloride when used in combination.

3. The results have experimentally substantiated applicability of "Glucosamine C-BCPP" dietary supplement as a protective agent on exposure to low temperatures.

\section{REFERENCES}

1. Ананьев В.Н. // Авиакосмическая и экол. медицина. - 2014. - T. 47, №4. - С. 5-6.

2. Андреев О.В., Фисталь Н.Н., Гиодуреи Д.П. // Вестник неотложной и восстановительной медицины. - 2005. - T. 6, №2. - C.247-249. 
3. Бондарєв С.В., Штриголь С.Ю. // Клін. фармачія. - 2010. - №4. - С. 47-49.

4. Бондарєв С.В., Штриголь С.Ю. // УБФЖ. - 2010. - №5 (10). - С. 60-65.

5. Гостищев В.К., Липатов К.В., Фархат Ф.А. // Актуальные вопросы гнойной хирургии // Матер. обл. науч.-практ. конф., посвященной 75-летию образования Московской области. - 2. Видное, 2004. - С. 30-31.

6. Дмитриев А. // Гражданская защита. - 2012. - №3. - C. 56-58.

7. Дрозд Ю.В., Бондаренко С.В., Яснечов В.В. и др. // Биол. эксперим. биол. имед. - 1991. - Т. 111, №4. - С. 383-384.

8. Зупанеи И.А. // Ортопедия, травматол. и протезирование. - 1994. - №4. - С. 105.

9. Олійник Г.А. // Медицина неотложных состояний. - 2013. - №8(55). Интернет издание «Новости медищины и фармачии».

10. Пат. 61166, Україна, А 61 К 31/726, А 61 Р 25/28 (2011). Застосування глюкозаміну гідрохлоридуяк антиамнестичного та антигіпоксичного засобу / С.В.Бондарєв, С.Ю.Штриголь, І.А.Зупанещь, О.С.Гріниова. - Заявл.: 21.12.2010. Опубл.: 11.07.2011. - Бюл. №13.

11. Руководство по проведению доклинических исследований лекарственных средств. Ч. I / Под ред. А.Н.Миронова. - М.: Гриф и К, 2012. - 944 с.

12. Семенков В.Ф., Карандашов В.И., Михайлова Т.А. // Вестник Рос. академии естественных наук. - 2011. - №4. - C. 72-78.

13. Слесаренко С.В., Козинеи Г.П.// Острые и неотложные состояния в практике врача. - 2010. - №1. - С. 9-13.

14. Степанян Ю.С. // Проблемы экспертизы в медичине. - 2009. - Т. 9, №4. - С. 21-23.

15. Трифонов С.В., Авхименко М.М., Трифонова С.С. // Медицинская помощьь. - 2007. - №1. - С. 28-32.

16. Biem J., Koehncke N., Classen D. et al. // CMAJ. - 2003. - Vol. 168 (3). - P. 305-311.

17. Effect of vitamin C on common cold: randomized controlled trial // Eur. J. Clin. Nutr. - 2006. - PubMed. NCBI]: ncbi.nlm.nih.gov.

18. Karlsen A.M., Thomassen O., Vikenes B.H. et al. // Scand. J. Trauma Resusc. Emerg. Med. - 2013. - Aug. 12. - P. 21-63. PMID: 23938145.

19. Lapostolle F., Sebbah J.L., Couvreur J. et al. // Crit. Care. - 2012. - №16. - P. 142.

20. Zafren K., Giesbrecht G.G., Danzl D.F. // Wilderness Environ Med. - 2014. - Dec. 25 (4). - P. S66-S85.

\section{ФРИГОПРОТЕКТОРНИЙ ЕФЕКТ ДІЄТИЧНОЇ ДОБАВКИ «ГЛЮКОЗАМІНУ С-БХФЗ» ТА РОЛЬ IIII КОМПОНЕНТІВ \\ Є.В.Бондарєє, С.Ю.Штриголь, Ю.Ю.Штриголь, А.С.Шаламай}

Ключові слова: фригопротекторна дія; глюкозаміну гідрохлорид; аскорбінова кислота; гостре загальне охолодження

Проведено визначення впливу дієтичної добавки «Глюкозамін С-БХФЗ» на тривалість життя тварин при гострому загальному охолодженні в експерименті на мишах. Встановлено, що при внутрішньошлунковому введенні тваринам дієтичної добавки Глюкозаміну С-БХФЗ (склад: глюкозаміну гідрохлорид та аскорбінова кислота) на моделі гострого загального охолодження спостерігається вірогідне підвищення часу життя стосовно групи контрольної патології. Фригопротекторний ефект добавки «Глюкозаміну С-БХФЗ» зумовлений переважно глюкозаміну гідрохлоридом, а роль аскорбінової кислоти менша.

\section{ФРИГОПРОТЕКТОРНЫЙ ЭФФЕКТ ДИЕТИЧЕСКОЙ ДОБАВКИ «ГЛЮКОЗАМИНА С-БХФЗ» И РОЛЬ ЕЕ КОМПОНЕНТОВ \\ Е.В.Бондарев, С.Ю.Штриголь, Ю.Ю.Штриголь, А.С.Шаламай}

Ключевые слова: фрригопротекторное действие; глюкозамина гидрохлорид; аскорбиновая кислота; острое общее охлаждение

Проведено определение влияния диетической добавки «Глюкозамина С-БХФЗ» на продолжительность жизни животных при остром общем охлаждении в эксперименте на мышах. Установлено, что при внутрижелудочном введении животным диетической добавки Глюкозамина С-БХФЗ (состав: глюкозамина гидрохлорид и аскорбиновая кислота) на модели острого общего охлаждения наблюдается достоверное повышение времени жизни относительно группыконтрольной патологии. Фригопротекторный эфрфект добавки «Глюкозамина С-БХФЗ» обусловлен преимущественно глюкозамина гидрохлоридом, а роль аскорбиновой кислоты меньше. 